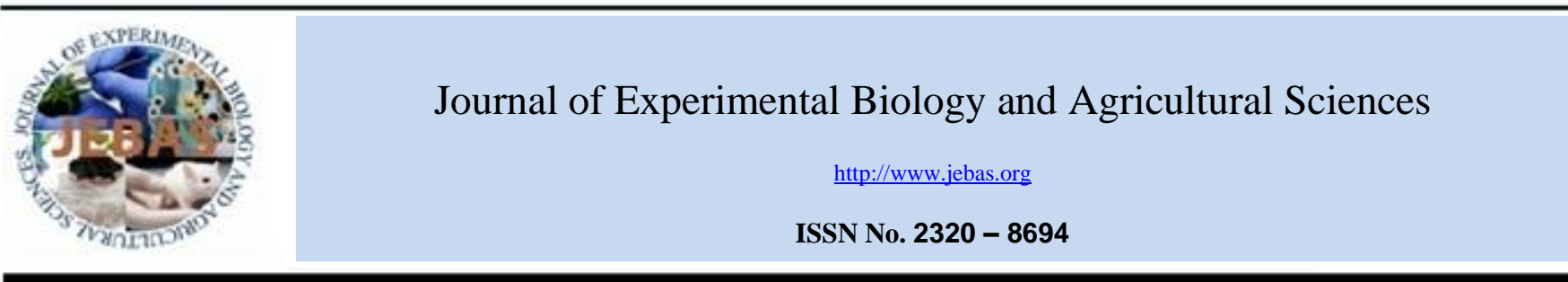

\title{
PRELIMINARY STUDY ON POTENTIAL EDIBLE COATINGS DERIVED FROM CARBOXYL METHYLCELLULOSE AND FUNGI CULTURED METABOLITES ON THE SHELF-LIFE EXTENSION OF SWEET-ORANGE (CITRUS SINENSIS)
}

\author{
Iyabo O Omomowo ${ }^{1}$, Afeez A Adedayo ${ }^{1}$, Olawale I Omomowo ${ }^{2}$, \\ Olusola N Majolagbe ${ }^{1}$, Adijat F Ogundola ${ }^{1}$
}

${ }^{1}$ Department of Pure and Applied Biology, Ladoke Akintola University of Technology, P.M.B. 4000, Ogbomoso, Oyo State, Nigeria

${ }^{2}$ Department of Microbiology, University of Maiduguri, P.M.B. 1069 Maiduguri, Maiduguri, Borno State, Nigeria

Received - July 27, 2021; Revision - October 05, 2021; Accepted - October 26, 2021

Available Online - October 30, 2021

DOI: http://dx.doi.org/10.18006/2021.9(5).663.671

\section{KEYWORDS \\ Orange fruits \\ Postharvest storage-life improvement \\ Bioactive metabolites \\ Eco-friendly coatings \\ Synergistic effects}

\begin{abstract}
This study focused on assessing the potential of formulated edible coatings derived from a metabolite of Trichoderma viride and Penicillium chrysogenum, combined with carboxyl methylcellulose (CMC) on the postharvest storage quality of orange fruits. The cultured metabolite of fungal bioagents combined with CMC, as well as glycerol (plasticizer), inadequate solution ratio based on wettability, was evaluated for microbiological quality and shelf-life extension of sweet orange. Thereafter, ascorbic acid, total soluble solids, $\mathrm{pH}$, percentage weight loss, among other parameters were assessed for 7 weeks. The results of the study revealed that the $\mathrm{pH}$ of $\mathrm{CMC}+$ Trichoderma viride and $\mathrm{CMC}+P$. chrysogenum coatings had $3.8 \pm 0.02$ and $3.17 \pm 0.06$ respectively, while it was reported $2.90 \pm 0.04$ for uncoated treatment. Also, the ascorbic acid and total soluble solids of the edible coated oranges were higher than the control. In addition, the percentage of weight loss was higher in the uncoated control compared to the potential edible coated oranges. Further, the microbial load count of the potential edible-coated oranges was less compared to the un-coated oranges. In conclusion, this formulated potential edible coating could be further improved upon and optimized for use in prolonging the storage of sweet oranges.
\end{abstract}

* Corresponding author

E-mail: afogundola@lautech.edu.ng (Ogundola Adijat Funke)

Peer review under responsibility of Journal of Experimental Biology and Agricultural Sciences.

Production and Hosting by Horizon Publisher India [HPI] (http://www.horizonpublisherindia.in/).

All rights reserved.
All the articles published by Journal of Experimental Biology and Agricultural Sciences are licensed under a Creative Commons Attribution-NonCommercial 4.0 International License Based on a work at www.jebas.org.

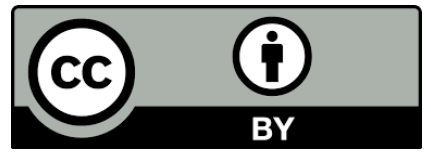




\section{Introduction}

The foremost fruit crop produced globally is citrus. It is cultivated in most of the nations of the world with well over a hundred million tons (Mahawar et al., 2020). Citrus fruit is globally accepted for its impact on human well-being. It is widely available and possesses enhanced dietary, nutritional, and other value-added bioactive properties along with superior taste (El-Otmani et al., 2011; Ghoshal, 2019). According to Mishra \& Patel (2020) consuming enough citrus fruits enhanced immunity and can reduce the disease incidence in human beings. Recently, the COVID-19 outbreak led to an increase in demand for fresh fruit worldwide.

However, yearly a significant percentage of harvested fruits are spoiled by pathogenic organisms (Onah et al., 2019). Post-harvest spoilage pathogens lead to the citrus fruit spoilage globally and make a loss in their economic and aesthetic value (Shi et al., 2018). Sweet oranges are prone to microbial infestations during the postharvest process of storing and transporting the fruit (Zhou et al., 2018). The optimum potential of commercial cultivation and consumption of citrus fruit in terms of value-added therapeutic advantages and economic impacts are being threatened due to the problem of postharvest microbial infestations, and lack of good post-harvest handling facilities, thereby leading to huge losses financially (Terao et al., 2017). It is estimated that food that is lost yearly throughout the world is in the range of over a billion tons (Ishangulyyev et al., 2019). Also, about 35\% of fruits and vegetables are part of these losses in a lot of countries.

Despite this challenging scenario, the collection of research funds is mainly focused on productivity enhancement of the foods (up to $95 \%$ ), while only $5 \%$ of investment is directed at research on food losses (Kitinoja \& Alhassan, 2012). The approach that is currently used in combating postharvest diseases of citrus fruits is by applying synthetic fungicides spray (Costa et al., 2019). However, there are various drawbacks associated with synthetic fungicides uses on edible orange fruits due to the cost implications, environmental pollution influence, and it also poses health hazards to mankind if some of these chemical residues remain on the orange fruit peels.

Hence, the trending scenario all over the world is an increase in public demand for a reduction in the use of fungicide, to produce healthy and eco-friendly safe "fruits", without chemical inputs for combating postharvest infestation of fruits (Padmaperuma et al., 2020). Metabolic activities such as transpiration and respiration occur in fresh fruits after their harvesting; thereby inducing textural changes and loss of water (Jalali et al., 2020; Nourozi \& Sayyari 2020). Thus, minimizing this bioactivity of fruits and vegetables postharvest is required through actions like the use of edible coatings thereby creating barrier/permeability to gaseous exchange (Md Nor \& Ding, 2020).
Edible coatings are a sustainable alternative that could be used as a postharvest treatment method for the benefit of perishable vegetables and fruits by extending their shelf life (Abhirami et al., 2020; Jafarzadeh et al., 2021). Edible coatings (Carboxymethylcellulose and Fungi cultured metabolites) are good alternatives to combat the menace of post-harvest losses of fruits and vegetables, thereby extending their shelf life (Amiri et al., 2021; IniguezMoreno et al., 2021). They are natural and eco-friendly options for tackling this huge problem (Tosati et al., 2017). However, the optimum result is not always attainable with just a single source of coating materials. Research reports indicated that edible coating materials that are combined synergistically with other bioactive materials and compounds perform better (Tosati et al., 2018; Yang et al., 2019).

This study is, therefore, focused on assessing the potential of deploying carboxyl methylcellulose in combination with cultured metabolites from two well-known rhizosphere-competent filamentous fungi, as bioactive forming coatings to extend the shelf-life of sweet oranges.

\section{Materials and Methods}

\subsection{Plant materials}

Sweet oranges (Citrus sinensis), without any diseased or injury symptoms, were freshly collected from an orchard and were quickly transported to the laboratory for processing. The oranges were rinsed under tap water and followed by surface sterilization with 3\% hypochlorite solution and $70 \%$ ethanol, and finally rinsed with sterile distilled water.

\subsection{Preparation of Carboxyl methylcellulose solution}

Carboxyl methylcellulose (CMC) sodium salt powder $1 \mathrm{~g} / \mathrm{L}$ was hydrolyzed in sterile water at $70^{\circ} \mathrm{C}$ for $2 \mathrm{~h}$, with constant stirring to obtain $1 \%(\mathrm{~W} / \mathrm{V})$ carboxyl methylcellulose solution.

\subsection{Culturing of Fungi in submerged liquid fermentation and extraction of metabolites}

Freshly prepared mycelia of $T$. viride and $P$. chrysogenum that was characterized in a previous study (Omomowo et al., 2020) were used to obtain the fermented cultured metabolites. The submerged liquid fermentation processing was done by using potato dextrose broth, under shaking incubation conditions at $150 \mathrm{rpm}$ for 7 days at $28^{\circ} \mathrm{C}$, to obtain the bioactive cultured metabolites used for bioactive coatings.

\subsection{Postharvest treatment and storage conditions of oranges}

The oranges were subjected to three treatments, using a combination of an equal volume of cultured metabolites of $T$. 
viride and $P$. chrysogenum combined with a $1 \%(\mathrm{~W} / \mathrm{V})$ carboxyl methylcellulose solution. The third treatment was the control experiment that entails dipping the oranges in sterilized distilled water only. The oranges were processed with the bioactive coating solutions as per the Jiang et al. (2005) protocol. Treated oranges were stored at $25^{\circ} \mathrm{C}$ with a relative humidity between $70-80 \%$ for the seven weeks.

\subsection{Determination of the firmness of the orange fruits}

The firmness of the treated fruits was determined using a penetrometer probe (Gong et al., 2020). This was calculated as the maximum force $(\mathrm{N})$ attained for tissue breakage. The result obtained with this probe was delineated in $\mathrm{Kg} / \mathrm{cm}^{-2}$.

\subsection{Determination of Percentage loss in weight of orange}

Loss in the weight of the treated and stored oranges was calculated by weighing orange fruit at the beginning of the experiment and reweighing it at the end of each week. It was calculated and expressed as a percentage, using the following equation.

$$
\text { Weight loss }(\%)=(\mathrm{M} 1-\mathrm{M} 2) / \mathrm{M} 1) \times 100
$$

Where $\mathrm{M}_{1}=$ Weight of orange fruit before bioactive coatings and storage.

$\mathrm{M}_{2}=$ Weight of orange fruit after bioactive coatings and storage in grams (Adetunji et al., 2018).

\subsection{Determination of $\mathbf{p H}$}

After orange fruit firmness analysis, the oranges were cut into small pieces (approximately $10 \mathrm{~g}$ equivalent) and homogenized in a grinder, while the supernatant was diluted with $100 \mathrm{ml}$ of distilled water and filtered. The solutions were titrated (phenolphthalein used as an indicator) to the endpoint of $\mathrm{pH} 8.2$ and the acidity result was taken as citric acid percentage equivalence. The $\mathrm{pH}$ of the samples was assessed using a $\mathrm{pH}$ meter (MonjazebMarvdashti et al., 2020).

\subsection{Determination of the Total SSC, and Ascorbic acid content}

The total soluble solid content of the oranges was evaluated using a hand refractometer with drops of orange fruit juice that had been previously extracted (Abd Allah et al. 2011).

Also, the ascorbic acid content was measured using the 2,6 dichlorophenolindophenol dye method (Deepa et al., 2006). Titration of the juice with Trichloroacetic acid (TCA) led to the color changing to pink. The results were delineated as ascorbic acid equivalent (AOAC, 2006).

\subsection{Microbiological analysis}

The effects of the bioactive forming coatings on the oranges were determined by doing a total microbial plate count for bacteria, yeasts, and mold. For this, $1 \mathrm{~g}$ of the treated and stored oranges were cut and dissolved in $9 \mathrm{ml}$ of sterile distilled water. 10-fold sample dilutions were carried out and inoculated on PDA medium and glucose yeast extract agars incorporated with antibiotics, and then it was incubated at $28{ }^{\circ} \mathrm{C}$ and the colony-forming units (CFU) of the incubated plates were counted after 5 days. Also, the total mesophilic and psychrophilic bacteria were determined following the same protocol on plate count agar, but incubation was for 48 hrs at $37{ }^{\circ} \mathrm{C}$. The (CFU) was observed in triplicate and represented as CFU $\times \mathrm{g}^{-1}$ (Sogvar et al., 2016; Shah et al., 2017).

\subsection{Data analysis}

The data analysis was subjected to Duncan's test which provided the significance level for the differences of any pair of means.

\section{Results}

\subsection{Fungal metabolites and carboxyl-methylcellulose as bioactive coatings}

The potential of the bioactive edible coatings, obtained from the cultured filtrates of the fungal bioagents, when combined with carboxyl methylcellulose was screened for the ability to increase the shelf life of orange by maintaining its post-harvest qualities. The experiment was conducted for 7 weeks. The results obtained indicated that the potential bioactive edible coatings gave better physiological and microbiological results after 7 weeks of postharvest treatment storage compared with the control. For illustration, at the end of the 7 weeks, the ascorbic acid level in the orange fruits coated with $\mathrm{CMC}+T$. viride solution was $5.8 \pm$ 0.04 while it was reported $4.7 \pm 0.04$ for the $\mathrm{CMC}+P$. chrysogenum bioactive solution (Table 1 ). These were better ascorbic acid content results, compared to the control having (4.0 $\pm 0.04)$. Also, the results obtained for the total soluble content of the orange fruits due to postharvest treatment with the potential bioactive edible coatings, indicated that after 7 weeks, the total soluble solid of fruits coated with $\mathrm{CMC}+P$. chrysogenum bioactive solution had the highest value of $3.22 \pm 0.01$, followed by the CMC $+T$. viride $(3.1 \pm 0.02)$ and control $(2.90 \pm 0.01)$. The result showed that potential bioactive edible-coated fruits performed significantly $(\mathrm{p}<0.05)$ better than the control after seven weeks of observation (Table 2). In addition, the effects of the potential edible coatings derived from carboxyl methylcellulose with metabolites of $T$. viride and $P$. chrysogenum on the $\mathrm{pH}$ of the postharvest treated orange fruits are shown in Table 3. After the 7 weeks of experimentation, the $\mathrm{pH}$ of fruits coated with $\mathrm{CMC}+T$. viride solution had the 
highest $\mathrm{pH}$ value of $3.8 \pm 0.02$, this was followed by $\mathrm{CMC}+P$. chrysogenum bioactive solution $(3.17 \pm 0.06)$ and the lowest $\mathrm{pH}$ value was observed in the control $(2.90 \pm 0.04)$. The result showed that potential bioactive edible-coated fruits performed better compared to un-coated control fruits. Furthermore, the resultant effects of potential bioactive edible coatings with carboxyl methylcellulose solution, combined with the cultured metabolites of $T$. viride and $P$. chrysogenum on the percentage weight loss of the orange fruits are illustrated in Table 4. After seven weeks of experimental storage, it was reported that potential bioactive edible-coated fruits performed significantly $(\mathrm{p}$ $<0.05$ ) better than the uncoated orange fruits, and the highest value of weight loss was reported $53 \pm 0.76$ percentage for the orange fruits used as uncoated control while this value was reported $44.0 \pm 0.4$ and $37 \pm 0.4$ for the $\mathrm{CMC}+P$. chrysogenum and $\mathrm{CMC}+T$. viride bioactive edible-coated respectively.

Table 1 Effect of potential bioactive edible coatings derived from carboxyl methylcellulose and fungal metabolites on ascorbic acid content

\begin{tabular}{|c|c|c|c|}
\hline Week(s) & $\begin{array}{l}\text { T. viride filtrates }+1 \%(\mathrm{CMC}) \mathrm{v} / \mathrm{v} \\
(\mathrm{CFU} / \mathrm{g})\end{array}$ & $\begin{array}{l}\text { P. chrysogenum filtrates }+1 \%(\mathrm{CMC}) \mathrm{v} / \mathrm{v} \\
\qquad(\mathrm{CFU} / \mathrm{g})\end{array}$ & $\begin{array}{c}\text { Control } \\
\text { (Sterile distilled water) }\end{array}$ \\
\hline 1 & $7.8 \pm 0.05^{\mathrm{a}}$ & $7.8 \pm 0.04^{\mathrm{a}}$ & $7.8 \pm 0.01^{\mathrm{a}}$ \\
\hline 2 & $7.5 \pm 0.04^{b}$ & $6.3 \pm 0.03^{b}$ & $6.0 \pm 0.15^{b}$ \\
\hline 3 & $7.4 \pm 0.04^{b}$ & $6.0 \pm 0.02^{\mathrm{c}}$ & $5.9 \pm 0.04^{b}$ \\
\hline 4 & $7.0 \pm 0.01^{\mathrm{c}}$ & $5.7 \pm 0.04^{\mathrm{d}}$ & $5.0 \pm 0.02^{\mathrm{c}}$ \\
\hline 5 & $6.5 \pm 0.04^{\mathrm{d}}$ & $5.3 \pm 0.08^{\mathrm{e}}$ & $4.7 \pm 0.08^{d}$ \\
\hline 6 & $6.3 \pm 0.06^{\mathrm{d}}$ & $5.1 \pm 0.04^{\mathrm{e}}$ & $4.3 \pm 0.08^{\mathrm{e}}$ \\
\hline 7 & $5.8 \pm 0.04^{\mathrm{e}}$ & $4.7 \pm 0.04^{\mathrm{f}}$ & $4.0 \pm 0.04^{\mathrm{f}}$ \\
\hline
\end{tabular}

Values are means \pm standard error. Means with similar alphabetical superscripts within a column is non-significant at $(\mathrm{P}<0.05)$

Table 2 Effect of potential bioactive edible coatings derived from carboxyl methylcellulose and fungal metabolites on the total soluble solids

\begin{tabular}{|c|c|c|c|}
\hline Week (s) & $\begin{array}{l}\text { T. viride filtrates }+1 \%(\mathrm{CMC}) \mathrm{v} / \mathrm{v} \\
(\mathrm{CFU} / \mathrm{g})\end{array}$ & $\begin{array}{l}\text { P. chrysogenum filtrates }+1 \%(\mathrm{CMC}) \mathrm{v} / \mathrm{v} \\
(\mathrm{CFU} / \mathrm{g})\end{array}$ & $\begin{array}{c}\text { Control } \\
\text { (Sterile distilled water) }\end{array}$ \\
\hline 1 & $5.53 \pm 0.01^{\mathrm{a}}$ & $5.53 \pm 0.04^{\mathrm{a}}$ & $5.53 \pm 0.01^{\mathrm{a}}$ \\
\hline 2 & $5.42 \pm 0.01^{b}$ & $4.21 \pm 0.01^{\mathrm{b}}$ & $4.21 \pm 0.01^{\mathrm{b}}$ \\
\hline 3 & $5.32 \pm 0.01^{\mathrm{c}}$ & $4.01 \pm 0.01^{\mathrm{c}}$ & $3.78 \pm 0.01^{\mathrm{c}}$ \\
\hline 4 & $4.92 \pm 0.01^{\mathrm{d}}$ & $3.92 \pm 0.01^{\mathrm{d}}$ & $3.51 \pm 0.01^{\mathrm{d}}$ \\
\hline 5 & $4.75 \pm 0.01^{\mathrm{e}}$ & $3.71 \pm 0.01^{\mathrm{e}}$ & $3.42 \pm 0.01^{\mathrm{d}}$ \\
\hline 6 & $4.62 \pm 0.01^{\mathrm{f}}$ & $3.41 \pm 0.01^{\mathrm{f}}$ & $3.11 \pm 0.04^{\mathrm{e}}$ \\
\hline 7 & $3.10 \pm 0.02^{\mathrm{g}}$ & $3.22 \pm 0.01^{\mathrm{g}}$ & $2.90 \pm 0.01^{\mathrm{f}}$ \\
\hline
\end{tabular}

Values are means \pm standard error. Means with similar alphabetical superscripts within a column is non-significant at $(\mathrm{P}<0.05)$.

Table 3 Effect of potential bioactive edible coatings derived from carboxyl methylcellulose and fungal metabolites on $\mathrm{pH}$ of orange fruits

\begin{tabular}{|cccc|} 
Week(s) & $\begin{array}{c}\text { T. viride filtrates }+1 \%(\mathrm{CMC}) \mathrm{v} / \mathrm{v} \\
(\mathrm{CFU} / \mathrm{g})\end{array}$ & $\begin{array}{c}P . \text { chrysogenum filtrates }+1 \%(\mathrm{CMC}) \mathrm{v} / \mathrm{v} \\
(\mathrm{CFU} / \mathrm{g})\end{array}$ & $\begin{array}{c}\text { Control } \\
(\text { Sterile distilled water })\end{array}$ \\
\hline 1 & $5.8 \pm 0.20^{\mathrm{a}}$ & $5.8 \pm 0.01^{\mathrm{a}}$ & $5.8 \pm 0.01^{\mathrm{a}}$ \\
\hline 2 & $5.2 \pm 0.10^{\mathrm{b}}$ & $4.6 \pm 0.10^{\mathrm{b}}$ & $4.3 \pm 0.10^{\mathrm{b}}$ \\
\hline 3 & $4.8 \pm 0.02^{\mathrm{c}}$ & $4.4 \pm 0.10^{\mathrm{b}}$ & $4.2 \pm 0.04^{\mathrm{bc}}$ \\
\hline 4 & $4.7 \pm 0.02^{\mathrm{cd}}$ & $4.2 \pm 0.10^{\mathrm{b}}$ & $4.0 \pm 0.10^{\mathrm{bc}}$ \\
\hline 5 & $4.5 \pm 0.02^{\mathrm{d}}$ & $3.8 \pm 0.04^{\mathrm{c}}$ & $3.8 \pm 0.10^{\mathrm{c}}$ \\
\hline 6 & $4.2 \pm 0.02^{\mathrm{e}}$ & $3.5 \pm 0.10^{\text {cd }}$ & $3.0 \pm 0.11^{\mathrm{d}}$ \\
\hline 7 & $3.8 \pm 0.02^{\mathrm{f}}$ & $3.17 \pm 0.06^{\mathrm{d}}$ & $2.9 \pm 0.04^{\mathrm{d}}$ \\
\hline
\end{tabular}

Values are means \pm standard error. Means with similar alphabetical superscripts within a column is non-significant at $(\mathrm{P}<0.05)$.

Journal of Experimental Biology and Agricultural Sciences http://www.jebas.org 
Table 4 Effect of potential bioactive edible coatings derived from carboxyl methylcellulose and fungal metabolites on percentage weight loss

\begin{tabular}{|c|c|c|c|}
\hline Week(s) & $\begin{array}{l}\text { T. viride filtrates }+1 \%(\mathrm{CMC}) \mathrm{v} / \mathrm{v} \\
(\mathrm{CFU} / \mathrm{g})\end{array}$ & $\begin{array}{l}\text { P. chrysogenum filtrates }+1 \%(\mathrm{CMC}) \mathrm{v} / \mathrm{v} \\
(\mathrm{CFU} / \mathrm{g})\end{array}$ & $\begin{array}{c}\text { Control } \\
\text { (Sterile distilled water) }\end{array}$ \\
\hline 1 & $25 \pm 0.40^{\mathrm{e}}$ & $23 \pm 1.13^{\mathrm{e}}$ & $25 \pm 0.76^{\mathrm{e}}$ \\
\hline 2 & $26 \pm 0.40^{\mathrm{e}}$ & $28 \pm 0.40^{\mathrm{d}}$ & $30 \pm 0.40^{\mathrm{d}}$ \\
\hline 3 & $28.67 \pm 0.60^{d}$ & $30 \pm 0.40^{\mathrm{d}}$ & $38 \pm 1.13^{\mathrm{c}}$ \\
\hline 4 & $31 \pm 0.40^{\mathrm{cd}}$ & $35 \pm 0.76^{c}$ & $40 \pm 0.76^{c}$ \\
\hline 5 & $33 \pm 0.40^{\mathrm{bc}}$ & $38 \pm 0.40^{\mathrm{b}}$ & $46 \pm 0.40^{\mathrm{b}}$ \\
\hline 6 & $35 \pm 0.40^{\mathrm{ab}}$ & $42 \pm 0.40^{\mathrm{a}}$ & $48 \pm 0.60^{\mathrm{b}}$ \\
\hline 7 & $37 \pm 0.40^{\mathrm{a}}$ & $44 \pm 0.40^{\mathrm{a}}$ & $53 \pm 0.76^{\mathrm{a}}$ \\
\hline
\end{tabular}

Values are means \pm standard error. Means with similar alphabetical superscripts within a column is non-significant at $(\mathrm{P}<0.05)$

Table 5 Effect of potential bioactive edible coatings derived from carboxyl methylcellulose and fungal metabolites on psychrophilic bacteria

\begin{tabular}{|cccc|} 
Week(s) & $\begin{array}{c}\text { T. viride filtrates }+1 \%(\mathrm{CMC}) \mathrm{v} / \mathrm{v} \\
(\mathrm{CFU} / \mathrm{g})\end{array}$ & $\begin{array}{c}\text { isolated from oranges } \\
P . \text { chrysogenum filtrates }+1 \%(\mathrm{CMC}) \mathrm{v} / \mathrm{v} \\
(\mathrm{CFU} / \mathrm{g})\end{array}$ & $\begin{array}{c}\text { Control } \\
\text { (Sterile distilled water) }\end{array}$ \\
\hline 1 & $2.3 \pm 0.04^{\mathrm{e}}$ & $2.27 \pm 0.06^{\mathrm{f}}$ & $2.3 \pm 0.08^{\mathrm{g}}$ \\
\hline 2 & $2.5 \pm 0.08^{\mathrm{e}}$ & $2.7 \pm 0.08^{\mathrm{e}}$ & $3.9 \pm 0.04^{\mathrm{f}}$ \\
\hline 3 & $2.8 \pm 0.04^{\mathrm{d}}$ & $3.87 \pm 0.06^{\mathrm{d}}$ & $5.7 \pm 0.08^{\mathrm{e}}$ \\
\hline 4 & $3.0 \pm 0.05^{\mathrm{d}}$ & $4.87 \pm 0.06^{\mathrm{c}}$ & $6.8 \pm 0.10^{\mathrm{d}}$ \\
\hline 5 & $3.4 \pm 0.04^{\mathrm{c}}$ & $5.2 \pm 0.08^{\mathrm{c}}$ & $7.8 \pm 0.07^{\mathrm{c}}$ \\
\hline 6 & $4.5 \pm 0.30^{\mathrm{b}}$ & $5.67 \pm 0.09^{\mathrm{b}}$ & $12.5 \pm 0.20^{\mathrm{b}}$ \\
\hline 7 & $4.8 \pm 0.04^{\mathrm{a}}$ & $6.27 \pm 0.06^{\mathrm{a}}$ & $18.3 \pm 0.08^{\mathrm{a}}$ \\
\hline
\end{tabular}

Values are means \pm standard error. Means with similar alphabetical superscripts within a column is non-significant at $(\mathrm{P}<0.05)$

Table 6 Effect of potential bioactive edible coatings derived from carboxyl methylcellulose and fungal metabolites on mesophilic bacteria

\begin{tabular}{c|ccc|} 
Week $(\mathrm{s})$ & $\begin{array}{c}\text { T. viride filtrates }+1 \%(\mathrm{CMC}) \mathrm{v} / \mathrm{v} \\
(\mathrm{CFU} / \mathrm{g})\end{array}$ & $\begin{array}{c}\text { isolated from oranges } \\
\text { P. chrysogenum filtrates }+1 \%(\mathrm{CMC}) \mathrm{v} / \mathrm{v} \\
(\mathrm{CFU} / \mathrm{g})\end{array}$ & $\begin{array}{c}\text { Control } \\
\text { (Sterile distilled water) }\end{array}$ \\
\hline 1 & $1.6 \pm 0.10^{\mathrm{d}}$ & $1.6 \pm 0.07^{\mathrm{f}}$ & $1.6 \pm 0.06^{\mathrm{g}}$ \\
\hline 2 & $2.3 \pm 0.04^{\mathrm{c}}$ & $2.33 \pm 0.02^{\mathrm{e}}$ & $3.4 \pm 0.01^{\mathrm{f}}$ \\
\hline 3 & $2.5 \pm 0.04^{\mathrm{c}}$ & $3.67 \pm 0.06^{\mathrm{d}}$ & $4.6 \pm 0.04^{\mathrm{e}}$ \\
\hline 4 & $2.5 \pm 0.04^{\mathrm{c}}$ & $4.3 \pm 0.04^{\mathrm{c}}$ & $5.2 \pm 0.10^{\mathrm{d}}$ \\
\hline 5 & $3.6 \pm 0.08^{\mathrm{b}}$ & $8.5 \pm 0.04^{\mathrm{b}}$ & $5.8 \pm 0.01^{\mathrm{c}}$ \\
\hline 6 & $3.8 \pm 0.04^{\mathrm{ab}}$ & $8.4 \pm 0.04^{\mathrm{b}}$ & $16.8 \pm 0.04^{\mathrm{b}}$ \\
\hline 7 & $3.93 \pm 0.06^{\mathrm{a}}$ & $8.9 \pm 0.02^{\mathrm{a}}$ & $19.3 \pm 0.08^{\mathrm{a}}$ \\
\hline
\end{tabular}

Values are means \pm standard error. Means with similar alphabetical superscripts within a column is non-significant at $(\mathrm{P}<0.05)$

\subsection{Potentials of bioactive coatings on microbial qualities of orange fruits}

The plate count results of the potential bioactive edible coatings revealed that the bioactive film-forming coating gave a decrease in microbial population during ambient storage conditions when compared to the uncoated fruits. The results presented in Table 5 indicated that the potential bioactive edible coatings led to the reduction of colony-forming units of psychrophilic bacteria. Further, the treatment containing $\mathrm{CMC}+T$. viride bioactive solution produced the lowest colony forming unit per gram (4.8 \pm $0.04 \mathrm{CFU} / \mathrm{g}$ ) at the end of the 7 weeks storage with followed by
$\mathrm{CMC}+P$. chrysogenum $(6.27 \pm 0.06 \mathrm{CFU} / \mathrm{g})$, while the highest value $(18.3 \pm 0.08 \mathrm{CFU} / \mathrm{g})$ was recorded for the uncoated control fruits.

Further, a similar trend of reduction in the number of mesophilic bacteria was observed due to the application of potential bioactive edible coatings on orange fruits (Table 6). Treatment with CMC + $T$ viride bioactive edible coatings produced the lowest colonyforming unit $(3.9 \pm 0.06 \mathrm{CFU} / \mathrm{g})$ at the end of the $7^{\text {th }}$ week while this was followed by $\mathrm{CMC}+P$. chrysogenum bioactive edible coating solution $(8.9 \pm 0.02 \mathrm{CFU} / \mathrm{g})$, while a higher value of $(19.3$ $\pm 0.08 \mathrm{CFU} / \mathrm{g}$ ) was recorded for the uncoated control fruits. 
Table 7 Effect of potential bioactive edible coatings derived from carboxyl methylcellulose and fungal metabolites on microbial load reduction of mold and yeast from oranges

\begin{tabular}{|cccc|} 
Week $(\mathrm{s})$ & $\begin{array}{c}\text { T. viride filtrates }+1 \%(\mathrm{CMC}) \mathrm{v} / \mathrm{v} \\
(\mathrm{CFU} / \mathrm{g})\end{array}$ & $\begin{array}{c}\text { P. chrysogenum filtrates }+1 \%(\mathrm{CMC}) \mathrm{v} / \mathrm{v} \\
(\text { CFU/g) }\end{array}$ & $\begin{array}{c}\text { Control } \\
\text { (Sterile distilled water) }\end{array}$ \\
\hline 1 & $1.2 \pm 0.01^{\mathrm{d}}$ & $1.2 \pm 0.11^{\mathrm{f}}$ & $1.2 \pm 0.08^{\mathrm{f}}$ \\
\hline 2 & $1.4 \pm 0.06^{\mathrm{cd}}$ & $1.6 \pm 0.05^{\mathrm{e}}$ & $1.8 \pm 0.08^{\mathrm{e}}$ \\
\hline 3 & $1.4 \pm 0.11^{\mathrm{cd}}$ & $1.9 \pm 0.07^{\mathrm{d}}$ & $2.7 \pm 0.04^{\mathrm{d}}$ \\
\hline 4 & $1.7 \pm 0.08^{\mathrm{c}}$ & $2.0 \pm 0.01^{\mathrm{d}}$ & $3.0 \pm 0.04^{\mathrm{d}}$ \\
\hline 5 & $2.3 \pm 0.08^{\mathrm{b}}$ & $2.5 \pm 0.06^{\mathrm{c}}$ & $3.7 \pm 0.06^{\mathrm{c}}$ \\
\hline 6 & $2.4 \pm 0.04^{\mathrm{b}}$ & $2.8 \pm 0.04^{\mathrm{b}}$ & $4.3 \pm 0.06^{\mathrm{b}}$ \\
\hline 7 & $2.8 \pm 0.01^{\mathrm{a}}$ & $3.9 \pm 0.08^{\mathrm{a}}$ & $5.8 \pm 0.12^{\mathrm{a}}$ \\
\hline
\end{tabular}

Values are means \pm standard error. Means with similar alphabetical superscripts within a column is non-significant at $(\mathrm{P}<0.05)$

More so, microbial load reduction of molds and yeasts was also attributed to the treatment of orange fruits using potential bioactive edible coatings as presented in (Table 7). Postharvest orange fruits treatments with $\mathrm{CMC}+T$. viride solutions produced the lowest colony-forming unit $(2.8 \pm 0.01 \mathrm{CFU} / \mathrm{g})$ at the end of the 7 weeks treatment storage with followed by $\mathrm{CMC}+P$. chrysogenum bioactive solution $(3.9 \pm 0.08 \mathrm{CFU} / \mathrm{g})$ and the highest value $(5.8 \pm$ $0.12 \mathrm{CFU} / \mathrm{g}$ ) was recorded for the uncoated control oranges. Generally, these results revealed that there was variation in the effects of the potential bioactive edible coatings on microbial populations of orange fruits.

\section{Discussion and conclusion}

A preliminary investigative study on the potential of bioactive edible coatings that were derived from the culture filtrates of two fungal bioagents was subjected to submerged liquid fermentation to obtain the metabolites, these metabolites were tested in combination with carboxyl methylcellulose solution to assess the synergistic effects on the postharvest shelf-life extension of sweet oranges during a 7-week experimental setup. The results of the study suggested good prospects in this preliminary screening investigation of the potential bioactive edible coatings. The population of the microbial load was reduced significantly due to the effects of the potential bioactive edible coatings on orange fruits. The plate count analysis indicated a reduction in the microbial counts of mesophilic and psychrophilic bacteria, as well as the molds and yeast count as reflected in their colony-forming units respectively. The $\mathrm{CMC}+T$. viride bioactive solution led to a reduction in the population of psychrophilic bacteria with a $(4.8 \pm$ $0.04 \mathrm{CFU} / \mathrm{g})$, while $(\mathrm{CMC}+P$. chrysogenum) bioactive solution gave microbial load value of $(6.27 \pm 0.06 \mathrm{CFU} / \mathrm{g})$. The highest microbial load value of $(18.3 \pm 0.08 \mathrm{CFU} / \mathrm{g})$ was recorded for the uncoated control fruits. Also, a similar trend was observed for the result of mesophilic bacteria population count, as well as the population of molds and yeast due to the potential bioactive edible coated orange fruits as compared with the uncoated control fruits. For example, the potential bioactive edible coated $(\mathrm{CMC}+P$. chrysogenum) orange fruits, had a mesophilic bacteria count of 8.9 $\pm 0.02 \mathrm{CFU} / \mathrm{g}$, and the highest mesophilic bacteria count was 19.3 $\pm 0.08 \mathrm{CFU} / \mathrm{g}$ which was recorded for the uncoated control fruits. These results imply that the potential bioactive edible coatings have antimicrobial properties that led to a reduction in the microbial count of the coated oranges when compared to the uncoated control of orange fruits. Earlier studies that are in agreement with our findings reported the efficacy of using edible coatings in improving the microbiological and physiological status of fruits and vegetables, thereby extending their storage life (Nayak et al., 2019; Nair et al., 2020; Pirozzi et al., 2021). According to the previous studies(Arnon et al. 2015; Chen et al. 2016; Munhuweyi et al. 2020; Zhao et al. 2020; Atta et al. 2021), the postharvest storage quality of fruits using carboxyl methylcellulose indicated an enhancement in the storage quality of the fruit attributable to the following mechanisms; the creation of hydrogen bond inside the CMC coating and forming of an extra layer of cuticle on the outer surface of the fruit. Also, the CMC coatings inhibited the proliferation of microbial life on the fruits, it reduces moisture loss and the rate of transpiration. More so, in a study on Agege sweet orange, Adetunji et al. (2018) utilize the synergistic influence of chitosan and $P$. aeruginosa produced rhamnolipid to extend the shelf-life of sweet orange through improving the microbial quality and physiological attributes of the coated oranges. These findings are incongruent with the highlights of our study that led to an improvement in both microbiological and physiological qualities of $C$. sinensis.

Also, various previous studies stated that the quality and shelf-life extension of fruits were improved, due to the treatment with various edible coatings (Maftoonazad \& Ramaswamy, 2019; Anjum et al., 2020; Jafarzadeh et al., 2021). The mechanisms of action or bioactivity of the edible coatings in improving the microbial and physiological quality of the treated fruits include production of antimicrobial, antioxidative enzymes, pathogenesis inducing protein, and other bioactive components to suppress microbial pathogens and also maintain the fruits physiological integrity (Nair et al., 2020; Tkaczewska, 2020). 
Our study further highlighted that there was minimal weight loss due to the application of the potential bioactive edible coatings on the orange fruits as compared to the uncoated control fruits. This result agrees with earlier studies of Abd El-Razek et al. (2019) and Abd-Elkader et al. (2021) where they reported and attributed the prevention of dehydration, loss of water, and fruit shrinkage to edible coatings of fruits. In addition, the application of the potential bioactive edible coatings significantly $(\mathrm{P}<0.05)$ improved the $\mathrm{pH}$, ascorbic acid, and the total soluble solid content of the orange fruits. This was due to the modifications of the internal environmental conditions of the coated fruits, thereby minimizing the exchange of gases due to the edible coatings and subsequently delaying the ripening of the fruits. These results are in harmony with reports of previous studies (Sharma et al., 2019; Parven et al., 2020; Xing et al., 2020; Hajebi Seyed et al., 2021; Hasan et al. 2021).

\section{Conclusion}

In conclusion, this preliminary investigative study on potential bioactive edible coatings that was formulated from a combination of carboxyl methylcellulose and fungal cultured metabolites led to significant improvement in the microbiological and physiological qualities of postharvest treated sweet orange fruits. The potential bioactive edible coatings led to a reduction in the microbial load of the citrus fruits, as well as improving the physiological qualities of the orange fruits. This implies that the potential bioactive edible can be deployed in enhancing the quality and storage life of sweet oranges (Citrus sinensis). Therefore, this study is an addition to the growing knowledge of using readily available natural bioactive ingredients to improve the shelf-life of very important orange fruit, thereby minimizing wastes, and ensuring the safety and security of fruits in our society. However, more questions are needed to be answered in further studies to comprehend the safety and mechanisms of action of this potential bioactive edible coating.

\section{Acknowledgments}

The authors did not receive any financial funding from an external body but are grateful to the authorities of LAUTECH for providing facilities.

\section{References}

Abd-Elkader DY, Salem MZM, Komeil DA, Al-Huqail AA, Ali HM, Salah AH, Akrami M, Hassan HS (2021) Post-Harvest Enhancing and Botrytis cinerea Control of Strawberry Fruits Using Low Cost and Eco-Friendly Natural Oils. Agronomy 11 (6):1246. doi:10.3390/agronomy11061246.

Abd El-Razek E, Abd El-Motty EZ, Orabi SA, Abou-Elfotouh A (2019) Improving Fruit Quality of Mango Fruits cv. Zebda by Coating with Moringa and Green Tea Leaves Extracts under cold
Storage. Middle East Journal of Agriculture Research 8 (4):13251343. doi:10.36632/mejar/2019.8.4.34.

Abd_Allah EF, Hashem A, Al-Huqail A (2011) Biologically-based strategies to reduce postharvest losses of tomato. African Journal of Biotechnology 10 (32):6040-6044.

Abhirami P, Modupalli N, Natarajan V (2020) Novel postharvest intervention using rice bran wax edible coating for shelf-life enhancement of Solanum lycopersicum fruit. Journal of Food Processing and Preservation 44 (12):1-11. doi:10.1111/jfpp.14989.

Adetunji CO, Adejumo IO, Afolabi IS, Adetunji JB, Ajisejiri ES (2018) Prolonging the shelf life of 'Agege Sweet' orange with chitosan-rhamnolipid coating. Horticulture, Environment, and Biotechnology 59 (5):687-697. doi:10.1007/s13580-018-0083-2.

Amiri S, Nicknam Z, Radi M, Sayadi M, Bagheri F, Karimi Khorrami N, Abedi E (2021) Postharvest quality of orange fruit as influenced by salicylic acid, acetic acid, and carboxymethyl cellulose coating. Journal of Food Measurement and Characterization 15:3912-3930. doi:10.1007/s11694-021-00966-y.

Anjum MA, Akram H, Zaidi M, Ali S (2020) Effect of gum arabic and Aloe vera gel based edible coatings in combination with plant extracts on postharvest quality and storability of 'Gola' guava fruits. Scientia Horticulturae 271:109506. doi:https://doi.org/10.1016/j.scienta.2020.109506.

Arnon H, Granit R, Porat R, Poverenov E (2015) Development of polysaccharides-based edible coatings for citrus fruits: A layer-bylayer approach. Food Chemistry 166:465-472. doi:https://doi.org/10.1016/j.foodchem.2014.06.061.

AOAC (2006) Official Methods of Analysis. 18th Edition, Association of Official Analytical Chemists, Gaithersburgs, MD.

Atta OM, Manan S, Ahmed AAQ, Awad MF, Ul-Islam M, Subhan F, Ullah MW, Yang G (2021) Development and Characterization of Yeast-Incorporated Antimicrobial Cellulose Biofilms for Edible Food Packaging Application. Polymers 13 (14):2310. doi:10.3390/polym13142310.

Chen CY, Zheng JP, Wan CP, Chen M, Chen JY (2016) Effect of carboxymethyl cellulose coating enriched with clove oil on postharvest quality of 'Xinyu' mandarin oranges. Fruits 71 (5):319-327. doi:10.1051/fruits/2016019.

Costa JH, Wassano CI, Angolini CFF, Scherlach K, Hertweck C, Pacheco Fill T (2019) Antifungal potential of secondary metabolites involved in the interaction between citrus pathogens. Scientific Reports 9 (1):1-11. doi:10.1038/s41598-019-55204-9. 
Deepa N, Kaur C, Singh B, Kapoor HC (2006) Antioxidant activity in some red sweet pepper cultivars. Journal of Food Composition and Analysis 19 (6):572-578. doi:https://doi.org/10.1016/j.jfca.2005.03.005.

El-Otmani M, Ait-Oubahou A, Zacarías L (2011) 21 - Citrus spp: orange, mandarin, tangerine, clementine, grapefruit, pomelo, lemon and lime. In: Yahia EM (Ed) Postharvest Biology and Technology of Tropical and Subtropical Fruits. Woodhead Publishing, pp 437-516e doi:https://doi.org/10.1533/9780857092762.437.

Ghoshal G (2019) 4 - Beverages: A Potential Delivery System for Nutraceuticals. In: Grumezescu AM, Holban AM (Eds) Nutrients in Beverages, vol 12. Academic Press, pp 111-142. doi:https://doi.org/10.1016/B978-0-12-816842-4.00004-6.

Gong HJ, Fullerton C, Billing D, Burdon J (2020) Retardation of 'Hayward' kiwifruit tissue zone softening during storage by 1methylcyclopropene. Scientia Horticulturae 259:108791. doi:https://doi.org/10.1016/j.scienta.2019.108791.

Hajebi Seyed R, Rastegar S, Faramarzi S (2021) Impact of edible coating derived from a combination of Aloe vera gel, chitosan and calcium chloride on maintain the quality of mango fruit at ambient temperature. Journal of Food Measurement and Characterization 15 (4):2932-2942. doi:10.1007/s11694-021-00861-6.

Hasan MU, Riaz R, Malik AU, Khan AS, Anwar R, Rehman RNU, Ali S (2021) Potential of Aloe vera gel coating for storage life extension and quality conservation of fruits and vegetables: An overview. Journal of Food Biochemistry 45 (4):e13640. doi:https://doi.org/10.1111/jfbc.13640.

Iñiguez-Moreno M, Ragazzo-Sánchez JA, Calderón-Santoyo M (2021) An Extensive Review of Natural Polymers Used as Coatings for Postharvest Shelf-Life Extension: Trends and Challenges. Polymers 13 (19):3271. doi:10.3390/polym13193271.

Ishangulyyev R, Kim S, Lee S (2019) Understanding Food Loss and Waste-Why Are We Losing and Wasting Food? Foods 8 (8):297. doi:10.3390/foods8080297.

Jafarzadeh S, Mohammadi Nafchi A, Salehabadi A, Oladzadabbasabadi N, Jafari SM (2021) Application of bio-nanocomposite films and edible coatings for extending the shelf life of fresh fruits and vegetables. Advances in Colloid and Interface Science 291:102405. doi:https://doi.org/10.1016/j.cis.2021.102405.

Jalali A, Linke M, Geyer M, Mahajan PV (2020) Shelf-life prediction model for strawberry based on respiration and transpiration processes. Food Packaging and Shelf Life 25:100525. doi:https://doi.org/10.1016/j.fpsl.2020.100525.
Jiang Y, Li J, Jiang W (2005) Effects of chitosan coating on shelf life of cold-stored litchi fruit at ambient temperature. LWT - Food Science and Technology 38 (7):757-761. doi:https://doi.org/10.1016/j.lwt.2004.09.004.

Kitinoja L, AlHassan HY (2012) Identification of appropriate postharvest technologies for small scale horticultural farmers and marketers in Sub-Saharan Africa and South Asia - PART 1. Postharvest losses and quality assessments. Acta Horticulturae 3140. https://doi.org/10.17660/ActaHortic.2012.934.1.

Maftoonazad N, Ramaswamy HS (2019) Application and Evaluation of a Pectin-Based Edible Coating Process for Quality Change Kinetics and Shelf-Life Extension of Lime Fruit (Citrus aurantifolium). Coatings 9 (5):285. doi:10.3390/coatings9050285.

Mahawar MK, Jalgaonkar K, Bibwe B, Bhushan B, Meena VS, Sonkar RK (2020) Post-harvest processing and valorization of Kinnow mandarin (Citrus reticulate L.): A review. Journal of Food Science and Technology 57 (3):799-815. doi:10.1007/s13197-01904083-z.

Md Nor S, Ding P (2020) Trends and advances in edible biopolymer coating for tropical fruit: A review. Food Research International 134:109208. doi:https://doi.org/10.1016/j.foodres.2020.109208.

Mishra S, Patel M (2020) Role of nutrition on immune system during COVID-19 pandemic. Journal of Food and Nutritional Health 3 (2):1-6.

Monjazeb Marvdashti L, Abdulmajid Ayatollahi S, Salehi B, Sharifi-Rad J, Abdolshahi A, Sharifi-Rad R, Maggi F (2020) Optimization of edible Alyssum homalocarpum seed gum-chitosan coating formulation to improve the postharvest storage potential and quality of apricot (Prunus armeniaca L.). Journal of Food Safety 40: e12805.

Munhuweyi K, Mpai S, Sivakumar D (2020) Extension of Avocado Fruit Postharvest Quality Using Non-Chemical Treatments. Agronomy 10 (2):212. doi:10.3390/agronomy 10020212.

Nair MS, Tomar M, Punia S, Kukula-Koch W, Kumar M (2020) Enhancing the functionality of chitosan- and alginate-based active edible coatings/films for the preservation of fruits and vegetables: A review. International Journal of Biological Macromolecules 164:304-320. doi:https://doi.org/10.1016/j.ijbiomac.2020.07.083.

Nayak SL, Sethi S, Sharma RR, Prajapati U (2019) Active Edible Coatings for Fresh Fruits and Vegetables. In: Gutiérrez TJ (ed) Polymers for Agri-Food Applications. Springer International Publishing, Cham, Pp 417-432. doi:10.1007/978-3-030-194161_21. 
Nourozi F, Sayyari M (2020) Enrichment of Aloe vera gel with basil seed mucilage preserve bioactive compounds and postharvest quality of apricot fruits. Scientia Horticulturae 262:109041. doi:https://doi.org/10.1016/j.scienta.2019.109041.

Omomowo IO, Adedayo AA, Omomowo OI (2020) Biocontrol Potential of Rhizospheric Fungi from Moringa oleifera, their Phytochemicals and Secondary Metabolite Assessment Against Spoilage Fungi of Sweet Orange (Citrus sinensis). Asian Journal of Applied Sciences 8 (1):1-14.

Onah G, Okogu S, Nebeife R (2019) Isolation and Identification of Microorganisms Involved in the Spoilage of Orange Fruit (Citrus sinensis) Sold in Some Selected Markets in Enugu Metropolis, Nigeria. IDOSR Journal of Scientific Research 4 (1):47-54.

Padmaperuma G, Butler TO, Shuhaili FABA, Almalki WJ, Vaidyanathan S (2020) Chapter 25 - Microbial consortia: Concept and application in fruit crop management. In: Srivastava AK, Hu C (Eds) Fruit Crops. Elsevier, Pp 353-366 doi:https://doi.org/10.1016/B978-0-12-818732-6.00025-3.

Parven A, Sarker MR, Megharaj M, Md. Meftaul I (2020) Prolonging the shelf life of Papaya (Carica papaya L.) using Aloe vera gel at ambient temperature. Scientia Horticulturae 265:109228. doi:https://doi.org/10.1016/j.scienta.2020.109228.

Pirozzi A, Ferrari G, Donsì F (2021) The Use of Nanocellulose in Edible Coatings for the Preservation of Perishable Fruits and Vegetables. Coatings 11 (8):990. doi:10.3390/coatings 11080990.

Shah S, Jahangir M, Qaisar M, Khan S, Mahmood T, Saeed M, Farid A, Liaquat M (2015) Storage Stability of Kinnow Fruit (Citrus reticulata) as Affected by CMC and Guar Gum-Based Silver Nanoparticle Coatings. Molecules 20 (12):22645-22661. doi:10.3390/molecules201219870.

Sharma P, Kehinde BA, Kaur S, Vyas P (2019) Application of edible coatings on fresh and minimally processed fruits: a review. Nutrition \& Food Science 49 (4):713-738. doi:10.1108/nfs-08-2018-0246.

Shi Z, Wang F, Lu Y, Deng J (2018) Combination of chitosan and salicylic acid to control postharvest green mold caused by Penicillium digitatum in grapefruit fruit. Scientia Horticulturae 233:54-60. doi:https://doi.org/10.1016/j.scienta.2018.01.039.

Sogvar OB, Koushesh Saba M, Emamifar A (2016) Aloe vera and ascorbic acid coatings maintain postharvest quality and reduce microbial load of strawberry fruit. Postharvest Biology and Technology 114:29-35. doi:https://doi.org/10.1016/ j.postharvbio.2015.11.019.
Terao D, de Lima Nechet K, Ponte MS, de Holanda Nunes Maia A, de Almeida Anjos VD, de Almeida Halfeld-Vieira B (2017) Physical postharvest treatments combined with antagonistic yeast on the control of orange green mold. Scientia Horticulturae 224:317-323. doi:https://doi.org/10.1016/ j.scienta.2017.06.038.

Tkaczewska J (2020) Peptides and protein hydrolysates as food preservatives and bioactive components of edible films and coatings - A review. Trends in Food Science \& Technology 106:298-311. doi:https://doi.org/10.1016/j.tifs.2020.10.022.

Tosati JV, de Oliveira EF, Oliveira JV, Nitin N, Monteiro AR (2018) Light-activated antimicrobial activity of turmeric residue edible coatings against cross-contamination of Listeria innocua on sausages. Food Control 84:177-185. doi:https://doi.org/10.1016/ j.foodcont.2017.07.026.

Tosati JV, Messias VC, Carvalho PIN, Rodrigues Pollonio MA, Meireles MAA, Monteiro AR (2017) Antimicrobial Effect of Edible Coating Blend Based on Turmeric Starch Residue and Gelatin Applied onto Fresh Frankfurter Sausage. Food and Bioprocess Technology 10 (12):2165-2175. doi:10.1007/s11947017-1985-1.

Xing Y, Yang H, Guo X, Bi X, Liu X, Xu Q, Wang Q, Li W, Li X, Shui Y, Chen C, Zheng Y (2020) Effect of chitosan/NanoTiO2 composite coatings on the postharvest quality and physicochemical characteristics of mango fruits. Scientia Horticulturae 263:109135. doi:https://doi.org/10.1016/ j.scienta.2019.109135.

Yang Z, Zou X, Li Z, Huang X, Zhai X, Zhang W, Shi J, Tahir HE (2019) Improved Postharvest Quality of Cold Stored Blueberry by Edible Coating Based on Composite Gum Arabic/Roselle Extract. Food and Bioprocess Technology 12 (9):1537-1547. doi:10.1007/s11947-019-02312-z.

Zhao H, Wang L, Belwal T, Jiang Y, Li D, Xu Y, Luo Z, Li L (2020) Chitosan-based melatonin bilayer coating for maintaining quality of fresh-cut products. Carbohydrate Polymers 235:115973. doi:https://doi.org/10.1016/j.carbpol.2020.115973.

Zhou Y, Ma J, Xie J, Deng L, Yao S, Zeng K (2018) Transcriptomic and biochemical analysis of highlighted induction of phenylpropanoid pathway metabolism of citrus fruit in response to salicylic acid, Pichia membranaefaciens and oligochitosan. Postharvest Biology and Technology 142:81-92. doi:https://doi.org/10.1016/j.postharvbio.2018.01.021. 